\title{
COMMENTARY:
}

\section{Cities spearhead climate action}

\author{
Mark Watts
}

\author{
Following President Trump's withdrawal from the Paris Agreement, cities worldwide have pledged \\ support to combat climate change. Along with a growing coalition of businesses and institutions, cities \\ represent a beacon of hope for carbon reduction in politically tumultuous times.
}

T he Paris Agreement on climate change aims to constrain global temperature rise to $1.5^{\circ} \mathrm{C}$ above pre-industrial levels. With the United States withdrawal, the rest of the world needs to focus on the urgency of building a new climate-safe future. In reality, we now have less than three years to ensure that greenhouse gas emissions have peaked and start to fall sharply.

Cities will inevitably play a key role in committing to such urgent action. Indeed, emissions from C40 cities - a network of 91 megacities dedicated to tackling climate change - need to have peaked by 2020 , and almost halved by 2030. Achieving this goal will require US $\$ 375$ billion in investment for low-carbon infrastructure in $\mathrm{C} 40$ cities over the next 3 years ${ }^{1}$. Now is not the moment to be pulling back from action on climate change, particularly in the case of the United States - the world's second largest source of greenhouse gases and a nation with one of the highest per capita emissions.

The global response to the US federal governments' withdrawal from the Paris Agreement has revealed a striking determination of mayors and city leaders to combat climate change. C40's board president and 108th mayor of New York City Michael R. Bloomberg pledged to give US $\$ 15$ million to the United Nations Climate Change Secretariat to compensate for the US share of the United Nations budget.

At the time of writing, more than 300 American mayors have committed to "adopt, honour and uphold the commitments to the goals enshrined in the Paris Agreement"2. Together these cities joined hundreds of US states, universities, and businesses to declare "We are still in" and committed to "pursue ambitious climate goals, working together to take forceful action and to ensure that the US remains a global leader in reducing emissions"3. Many of the same leaders are now working on the creation of America's Pledge, an

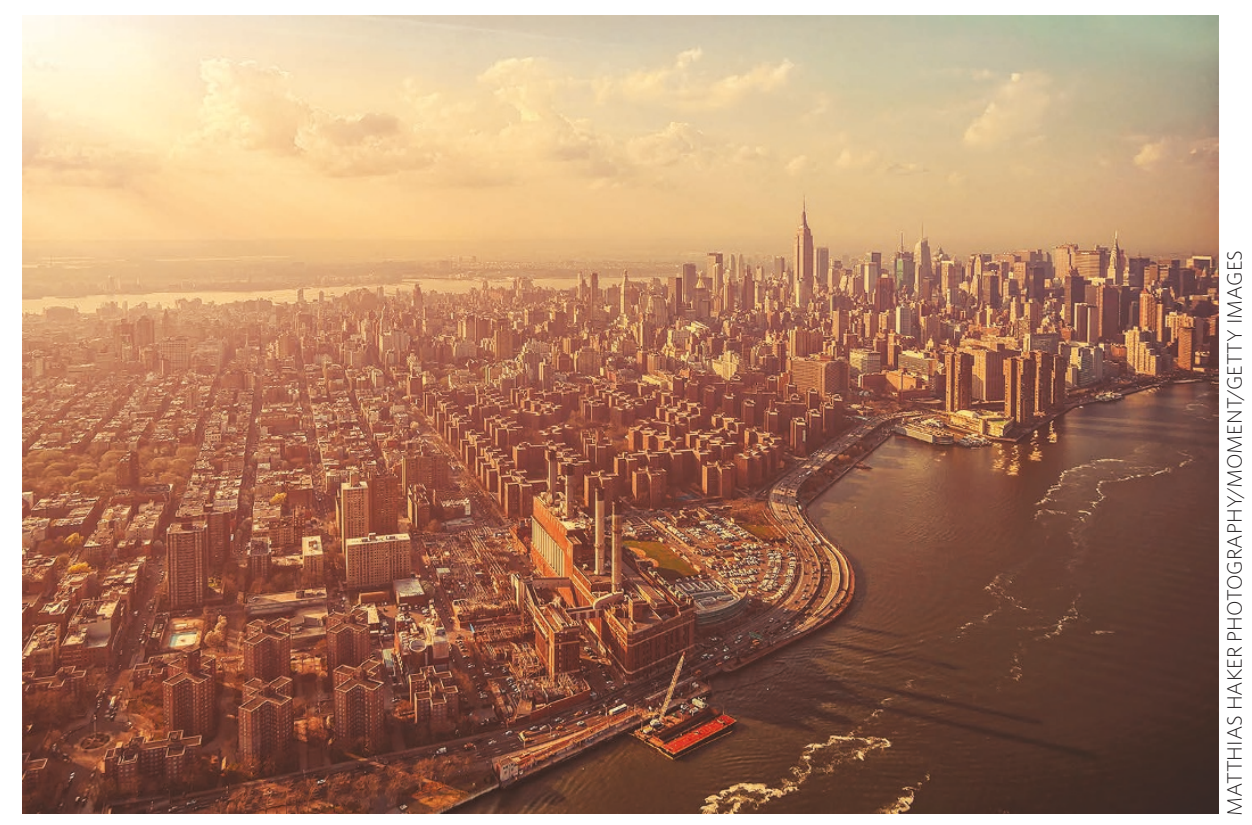

unprecedented effort to aggregate carbon reductions by cities, regions, businesses and other social actors to ensure that the US achieves its Paris Agreement pledge.

City mayors are taking matters into their own hands, passing legislation and delivering policies compatible with the Paris Agreement. The mayors of Portland and Pittsburgh have announced $100 \%$ renewable energy targets for their cities, and the mayors of New York City, Chicago, and Washington DC have signed executive orders to make the goals of the Paris Agreement their own. Many more mayors are set to follow.

The regulatory environment created by the Federal Government is certainly important. Yet mayors are proving remarkably adept at finding ways to deliver low-carbon policies and projects. In March 2017, 30 American cities, including Los Angeles, New York and Chicago, jointly informed vehicle manufacturers that they would be purchasing 114,000 electric vehicles such as police cars, rubbish trucks and buses in the years ahead. This announcement illustrates the potential scale of the market in electric vehicles and the purchasing power of cities. American automakers are expected to launch a major research and development investment in electric vehicle technology to respond to this huge new market ${ }^{4}$.

City leaders outside of the United States were also swift and united in their condemnation of President Trump's decision. More than 50 cities, from Sydney to Mexico City, Stockholm to Seoul, lit their city halls or their iconic monuments in green, as a sign of their commitment to the Paris Agreement ${ }^{5}$. President Trump justified his decision on the Paris Agreement by saying he was "elected to represent the citizens of Pittsburgh not Paris". Within minutes the Mayor of Pittsburgh, Bill Peduto, had pledged his support for the Paris Agreement. Days later, Mayor Peduto, alongside the Mayor of Paris and C40's Chair, Anne Hidalgo, penned a joint editorial in the New York Times; they noted 
"the only way to do right by Pittsburghers and Parisians is to abide by the principles of the Paris Agreement, which guarantees the future health and prosperity of both of our cities - and every other city in the world"6.

Mayors of the world's great cities are leading a sustainable and low-carbon revolution in our urban communities. From the rollout of fleets of electric buses in Chinese cities; efforts by European, South American and Indian cities to ban the most polluting cars from city centres; to the retrofitting of tens of thousands of buildings across North American cities to deliver greater energy efficiency and dedicated low-carbon districts in cities worldwide, mayors are taking bold actions to cut emissions and prepare for the worst effects of climate change.

They are not doing this just because it is necessary to protect a global environment in which humanity can survive, but because it will benefit their citizens right now. C40 mayors have no doubt that cities which adapt to the realities of a changing climate and clean up pollution will be the most popular places to live, where living standards rise fastest and economic development is most sustained. Climatefriendly policies make citizens healthier and wealthier, creating jobs whilst reducing inequality. The solar and wind industries, for example, are each creating jobs at a rate 12 times faster than that of the rest of the US economy ${ }^{7}$. According to the New Climate Economy, transit-oriented urban development could reduce per household expenditure on travel by $20 \%$ in the US.

Mayors of the world's cities understand that there is no alternative to urgent, bold and transformative action against climate change. By the end of 2020, every C40 city will have a plan in place to ensure they can deliver on their obligations to the Paris Agreement. President Trump's decision to abandon the Paris Agreement is undeniably a major setback in the global fight against climate change, yet it has brought welcome attention to the efforts and commitment of cities, both in the US and beyond, on climate action. They are being joined by a growing coalition of businesses, institutions and citizens that has the potential to lead a global climate revolution.

Mark Watts is at C40 Cities Climate Leadership Group, 39-45 Finsbury Square, London EC2A 1PX, UK.

e-mail:media@c40.org

\section{References}

1. Deadline 2020: How Cities will get the Job Done (C40/ARUP, 2016).

2. 343 US Climate Mayors commit to adopt, honor and uphold Paris climate agreement goals. Medium (1 June 2017).

3. We Are Still In (WWF/Ceres, 2017); http://go.nature.com/2txjEru

4. Ryan, J. Cities shop for $\$ 10$ billion of electric cars to defy Trump. Bloomberg (14 March 2017).

5. Livsey, A. City halls and landmarks turn green in support of Paris climate deal. Guardian (2 June 2017)

6. Hidalgo, A. \& Peduto, W. The mayors of Pittsburgh and Paris: we have our own climate deal. New York Times (7 June 2017).

7. Samuelson, K. Renewable energy is creating jobs 12 times faster than the rest of the economy. Fortune (27 January 2017).

\title{
Stop preaching to the converted
}

\author{
Asheley R. Landrum and Robert B. Lull
}

\section{Traditional moral arguments fail to persuade conservative climate sceptics. Pope Francis' gifting of his climate encyclical to President Trump prior to his leaving the Paris Agreement shows that even a religious leader's persuasive power is constrained by how his message resonates with conservative moral values.}

\author{
n June 2015, Pope Francis' encyclical \\ Laudato Si: On Care of Our Common \\ Home received considerable attention \\ as an official Catholic document urging \\ global climate change mitigation. As the \\ spiritual leader of over 1 billion Catholics \\ throughout the world, it was anticipated \\ that Pope Francis was well-positioned to \\ appeal to his followers' moral sensibilities \\ and perhaps initiate broader impact given \\ his popularity among the general public ${ }^{1}$. \\ Almost two years later, on 24 May 2017, \\ Pope Francis met with US president, \\ Donald Trump, who on multiple occasions \\ has expressed scepticism about the \\ existence of climate change. The Pope gave \\ President Trump a copy of the encyclical, \\ presumably hoping to convince Trump \\ to reconsider his views on climate change \\ and his plan to withdraw from the Paris \\ Agreement on climate. Optimistically, \\ senate minority leader Chuck Schumer
}

said, "If President Trump reads the Pope's writing, I'm confident he'll not withdraw the [Paris] agreement. We've gotta get him to read it." ${ }^{2}$

We did not share Senator Schumer's confidence. Not only was President Trump, like most Americans, unlikely to read the 40,000 word document, but our work and that of our colleagues suggests that familiarity with the encyclical was not sufficient to alter US conservatives' climate change attitudes ${ }^{3,4}$. Believing that President Trump - a US president representing the conservative Republican party - would react any differently to the average conservative survey respondent represented naïve optimism with minimal empirical justification.

Unsurprisingly, a week later President Trump announced his plan to withdraw from the Paris Agreement, stating "The Paris climate accord is simply the latest example of Washington entering into an agreement that disadvantages the United States to the exclusive benefit of other countries, leaving American workers - who I love - and taxpayers to absorb the cost in terms of lost jobs, lower wages, shuttered factories, and vastly diminished economic production."

\section{The importance of values}

President Trump's statement stressed conservative values, citing potential job losses and concern about restrictions on business while affirming his loyalty to the American public (versus the rest of the world) and his fears that the agreement puts the US at a disadvantage compared to other foreign powers. Yet prior to President Trump's announcement, many people shared Senator Schumer's optimism that Pope Francis' moral arguments, such as his assertion that climate change 